\title{
One-Pot Synthesis of NEMP, a VX Surrogate, and Reactivation of NEMP-Inhibited Electrophorus Eel Acetylcholinesterase by Current Antidotes
}

\author{
Samir F. A. Cavalcante, ${ }^{\oplus *, a, b}$ Daniel A. S. Kitagawa, ${ }^{a, c}$ Rafael B. Rodrigues, ${ }^{a}$ \\ Taynara C. Silva, ${ }^{a}$ Leandro B. Bernardo, ${ }^{a}$ Ana Beatriz A. Correa ${ }^{a}$ and \\ Alessandro B. C. Simas ${ }^{\circledR} *, b$ \\ a'Instituto de Defesa Química, Biológica, Radiológica e Nuclear (IDQBRN), Exército Brasileiro, \\ Avenida das Américas 28705, Área 4, 23020-470 Rio de Janeiro-RJ, Brazil \\ ${ }^{b}$ Instituto de Pesquisas de Produtos Naturais Walter Mors (IPPN), Bloco H, HSS-27, \\ Universidade Federal do Rio de Janeiro (UFRJ), 21941-902 Rio de Janeiro-RJ, Brazil
}

'Instituto Militar de Engenharia (IME), Praça General Tibúrcio 80, 22290-270 Rio de Janeiro-RJ, Brazil

The use of nerve agents, organophosphorus compounds which irreversibly inhibit acetylcholinesterase, in conflicts and terrorism has gained renewed geopolitical status in recent years. As no "universal antidote" has ever been produced, the development of antidotes to reactivate enzyme is clearly warranted. Given the fact that nerve agents are restricted substances, the use of surrogates allows non-qualified laboratories to develop research on novel antidotes. We herein present an alternative and efficient synthesis of NEMP, $O$-(4-nitrophenyl) $O$-ethyl methylphosphonate, a venomous agent X (VX) surrogate, and Ellman's test procedures for inhibition and reactivation of Electrophorus eel acetylcholinesterase involving the NEMP-generated adduct.

Keywords: nerve agents' surrogates, VX, Ellman's test, acetylcholinesterase, drug screening

\section{Introduction}

The period between the Great Wars and later on, during the Cold War, experienced the development of a series of organophosphorus compounds initially designed as pesticides. Due to their high toxicity, they soon were deemed as weaponizable compounds. ${ }^{1-3}$

These compounds are under strict control by international agreements, being the most important the Chemical Weapons Convention (CWC), which entered into force in 1997, and deals with controls and obligations related to the unlawful use of toxic chemicals, amid other issues. CWC has led to the creation of Organization for the Prohibition of Chemical Weapons (OPCW), a multilateral, international watchdog, overseeing CWC implementation. Among these toxic chemicals are potent acetylcholinesterase (AChE) inhibitors, classified as nerve agents. In the Article II of CWC, toxic chemicals are referred to as "any chemical which through its chemical action on life processes can cause death,

*e-mail: samir.cavalcante@eb.mil.br; abcsimas@nppn.ufrj.br temporary incapacitation or permanent harm to humans or animals. The related restrictions apply to such chemicals, regardless of their origin or of their method of production, and regardless of whether they are produced in facilities, in munitions or elsewhere". ${ }^{1,4}$

The Annex on Chemicals of CWC classifies compounds that have "been developed, produced, stockpiled or used as a chemical weapon", but CWC allows certified laboratories to produce small, declarable amounts of weaponizable substances for research purposes. CWC lists in its Schedule 1 on the Annex on Chemicals compounds with little or no peaceful uses. ${ }^{1,4}$ Examples of such compounds are depicted in Figure 1. Sarin (1), soman (2), cyclosarin (3), tabun (4) and V-agents (venomous agent X, VX, 5; Russian-VX or VR, 6) are representative examples. ${ }^{4}$ Recently, Novichok agents (A-232, 7), which are also potent $\mathrm{AChE}$ inhibitors, have been confirmed. They pose a high risk, as they have been created to circumvent CWC, and their toxicity is predicted to be much higher than VX. ${ }^{5}$

The historic and recent use of these compounds in different conflicts and assassination attempts have attracted attention of governments, multilateral organizations and 
<smiles>CC(C)OP(C)(=O)F</smiles>

1

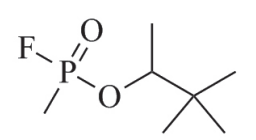

2<smiles>CP(=O)(F)OC1CCCCC1</smiles>

3<smiles>CCOP(=O)(C#N)N(C)C</smiles>

4<smiles>CCOP(C)(=O)SCCN(C(C)C)C(C)C</smiles>

5

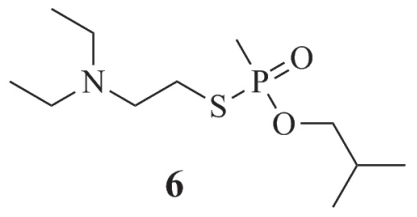<smiles>CCOP(=O)(F)/N=C(\C)N(CC)CC</smiles>

7

Figure 1. Structures of representative nerve agents.

the public. ${ }^{6-10}$ Different research groups have set forth efforts on the development of novel antidotes, as there is no "universal antidote" to reactivate inhibited AChE (EC 3.1.1.7), ${ }^{11-17}$ a serine-estearase enzyme (8), biological target of nerve agents. This enzyme is responsible for the breakdown of acetylcholine (9), the neurotransmitter in the parasympathetic neurotransmission (Scheme 1), into acetate (10) and choline (11). Scheme 2 depicts the formation of sarin-AChE adduct (12), responsible for the loss of enzymatic function. Broad AChE inhibition may lead to SLUDGEM syndrome (salivation, lacrimation, urination, defecation, gastrointestinal disturbs, emesis, miosis and muscle spasms), which can be fatal. This is triggered by overstimulation of cholinergic innervations, owing to acetylcholine accumulation in the synaptic cleft.

The therapeutic approach to reactivating AChE resorts to the use of compounds which are able to form nucleophilic oxygen at physiological conditions. In addition, such active molecules usually bear a cationic nitrogen atom in order to mimic the choline moiety, which improves reactivation due to additional interactions with other enzymatic sites besides the catalytic one. ${ }^{18-27}$ Pyridinium oximes are the only motif

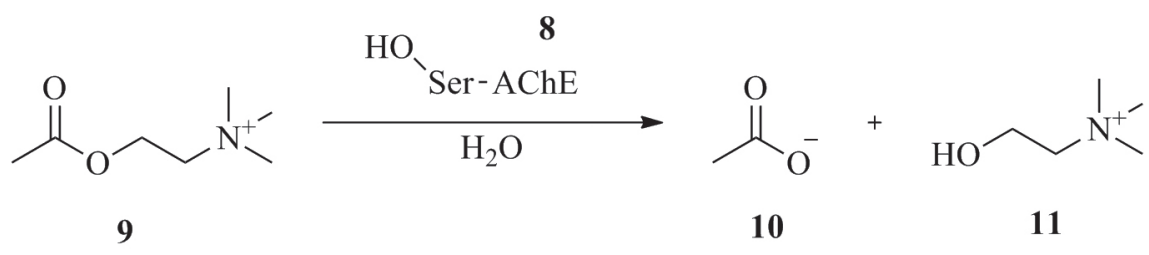

Scheme 1. Breakdown of acetylcholine by AChE.

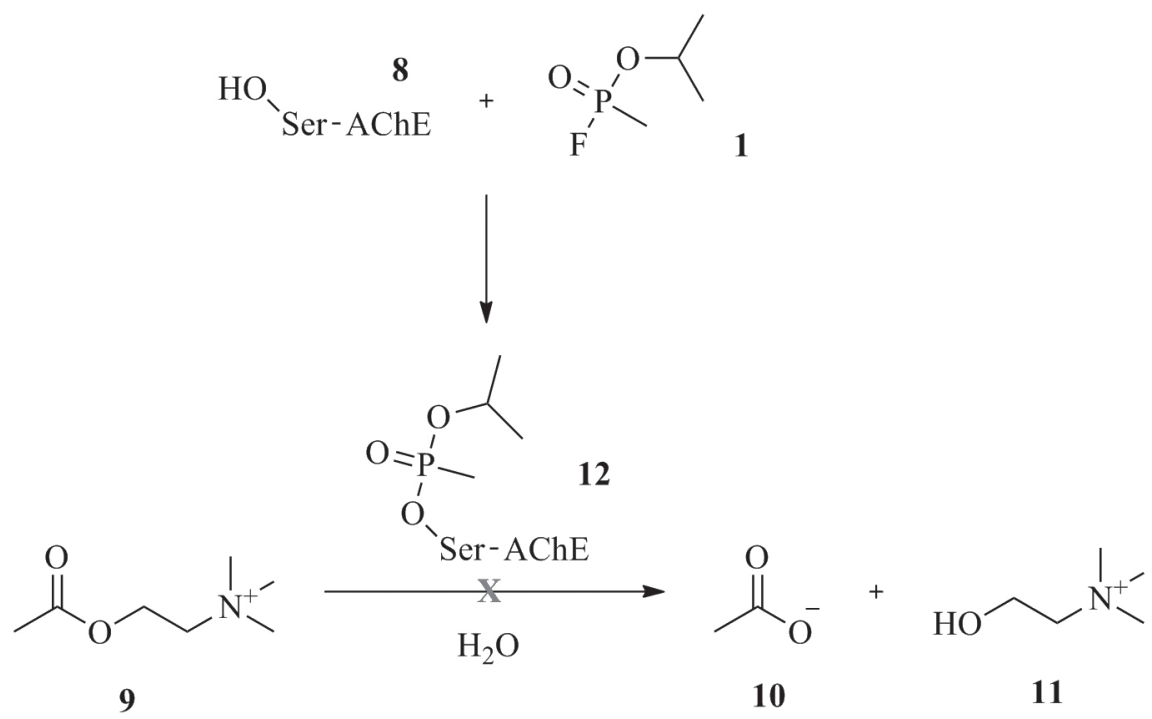

Scheme 2. Inhibition of acetylcholine by sarin. 
which has matched these factors. ${ }^{28-30}$ Figure 2 exemplifies relevant oximes: pralidoxime (2-PAM, 13), obidoxime (OBD, 14), trimedoxime (TMB, 15), K027 (16), asoxime (HI-6, 17) and HLö-7 (18).

Scheme 3 shows how the oximate (19) generated in vivo from pralidoxime (13) reacts with phosphonylated enzyme (12), removing the phosphorus moiety from the serine residue. This reaction yields a phosphonyloxime (20), a detoxification product, and the reactivated enzyme $(\mathbf{8}){ }^{31-36}$
Nonetheless, non-certified research facilities may face difficulties in developing novel antidotes given the impossibility of use of authentic nerve agents, as these do not comply with requirements to work with these chemicals. In accordance to $\mathrm{CWC},{ }^{4}$ facilities that produce Schedule 1 chemicals must declare their activities and may be subject of inspection twice a year. To overcome this limitation, surrogates may be valuable, as they are less toxic and volatile than the actual nerve agents, but yield<smiles>[Y]c1ccccc1/C=N/O</smiles>

13<smiles>[Y20]C[n+]1ccc(/C=N/O)cc1</smiles>

14<smiles>[Y20]CCC[n+]1ccc(/C=N/O)cc1</smiles><smiles>[Y20]C[n+]1ccccc1/C=N/O</smiles><smiles>[Y20]COC[n+]1ccc(C(N)=O)cc1/C=N/O</smiles>

Figure 2. Some clinically available antidotes ( $\mathrm{X}$ may be chloride, bromide, iodide or methanesulfonate).<smiles>C[n+]1ccccc1/C=N/O</smiles>

13<smiles>CC#CC=N[O-]</smiles>

19<smiles>C[n+]1ccccc1/C=N/[O-]</smiles>

19<smiles>CC(C)OP(C)(=O)O[Ge]C(C)C</smiles><smiles>CC(C)OP(C)(=O)O/N=C/c1cccc[n+]1C</smiles>

$\mathrm{HO}$ Ser-AChE

Scheme 3. Reactivation of sarin-inhibited AChE by pralidoxime. 
the same enzyme adduct and whose use is not prohibited according to CWC. ${ }^{4}$ For VX, $O$-(4-nitrophenyl) $O$-ethyl methylphosphonate (NEMP, 21, Figure 3) is a known surrogate, which has been synthesized by a different approach.$^{37}$ In accordance to CWC Annex on Chemicals, ${ }^{4}$ it is classified as Schedule 2.B.04 chemical.

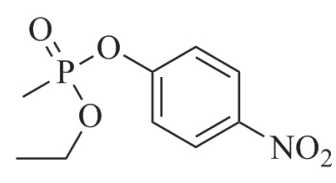

21

Figure 3. $O$-(4-Nitrophenyl) $O$-ethyl methylphosphonate (NEMP).

Recently, we reported the synthesis of NEMP starting from triethyl phosphite, in a two-step procedure ${ }^{38} \mathrm{We}$ herein present a one-pot synthesis of this VX surrogate from $O, O$-diethyl methylphosphonate, which does not require purification steps as it yields NEMP in the required purity for toxicological and biochemical assessments. We have also undertaken Ellman's tests for characterization of inhibition of commercially available Electrophorus eel $\mathrm{AChE}(E e \mathrm{AChE})$ by herein synthesized NEMP and for enzyme reactivation by known antidotes. Ellman's tes ${ }^{39,40}$ is a spectrophotometry-based assay to measure thiol groups in different matrices, useful for evaluation of molecules that can interact with AChE. ${ }^{41-47}$

\section{Experimental}

\section{Materials and reagents}

Oxalyl chloride was purchased from TCI America Brazil (São Paulo, Brazil). Acetylthiocholine iodide, 5,5'-dithiobis-(2-nitrobenzoic) acid (DTNB), lyophilized acetylcholinesterase from Electrophorus eel (EeAChE, 1000 U per mg protein, type V-S, C2888), 2-PAM, $\mathrm{N}, \mathrm{N}$-dimethylformamide (DMF, dry, oxygen-free sealed bottle), dimethyl sulfoxide (DMSO, biological grade, dry, oxygen-free sealed bottle), triethylamine (dry, oxygen-free sealed bottle), diethyl methylphosphonate, dichloromethane (dried over $4 \AA$ A molecular sieves before use), toluene (dried over $4 \AA$ molecular sieves before use), sodium hydroxide (pellets), anhydrous sodium sulfate, sodium phosphate monobasic hydrate and sodium phosphate dibasic dihydrate were purchased from Sigma-Aldrich (São Paulo, Brazil). Absolute ethanol was purchased from Tedia (Rio de Janeiro, Brazil). Hydrochloric acid was purchased from Vetec (Rio de Janeiro, Brazil). Deuterated solvents $\left(\mathrm{CDCl}_{3}\right.$ and DMSO- $d_{6}$ ) containing tetramethylsilane as internal standard were purchased from Cambridge Isotopes Laboratories (Tewksbury, Massachusetts, USA). Obidoxime dichloride (OBD, 14) and trimedoxime dibromide (TMB, 15) were synthesized in accordance to literature ${ }^{48,49}$ and their physical data were compatible. Purified water was obtained from Millipore Milli-Q system $\left(18.2 \mathrm{M} \Omega \mathrm{cm}\right.$ at $25^{\circ} \mathrm{C}$, Millipore Brazil, São Paulo, Brazil). Biotage Initiator 8 (Charlotte, North Carolina, USA) was used for synthesis of all oximes. Sealed tubes (Q-Tube) were purchased from Q-Labtech (East Lyme, Connecticut, USA). TLC (thin layer chromatography) aluminum plates coated with silica gel $\mathrm{F}_{254}$ were purchased from Merck Brazil (São Paulo, Brazil). Camag TLC-MS (thin layer chromatography-mass spectrometry) interface was used to follow up reactions (AuTeC, São Paulo, Brazil). Nuclear magnetic resonance (NMR) spectra was obtained from Varian Unity $400 \mathrm{MHz}$ (Palo Alto, California, USA) and Bruker Avance $400 \mathrm{MHz}$ (Billerica, Massachusetts, USA) and referred to tetramethylsilane for ${ }^{1} \mathrm{H}$ and ${ }^{13} \mathrm{C}$ NMR spectra and to phosphoric acid for ${ }^{31} \mathrm{P}$ NMR. GC-MS (gas chromatography-mass spectrometry) data were obtained from Agilent 6890 GC system (Santa Clara, California, USA) equipped with 5975C mass spectrometer detector. LC-MS (liquid chromatography-mass spectrometry) data were obtained from Agilent 1210 LC system (Santa Clara, California, USA) equipped with 6410B triple quadrupole mass spectrometer detector. Kasvi 96-wells microplates were purchased from Kasvi Brasil (São José dos Pinhais, PR, Brazil); Gilson single channel pipettes, from Gilson Inc. (Middleton, Wisconsin, USA) and Eppendorf 8-channel pipettes, from Eppendorf Brasil (São Paulo, Brazil). Ellman's tests were performed in triplicate, in three different assays, by at least three different operators, measured at $24 \pm 2{ }^{\circ} \mathrm{C}$. All disposable materials and glassware in contact with organophosphorus compounds were decontaminated with aqueous solution containing $10 \% \mathrm{~m} / \mathrm{v} \mathrm{NaOH}$ and $10 \% \mathrm{~m} / \mathrm{v}$ $\mathrm{NaClO}$ for $48 \mathrm{~h}$ at room temperature before correct destination and cleaning. Estimations of $\mathrm{p} K_{\mathrm{a}}$ and $\log \mathrm{P}$ for clinical antidotes were obtained from ChemAxon Online Suite. Solubility and partition coefficient $\mathrm{K}_{\mathrm{OW}}$ (octanol/ water) estimations were obtained from USEPA EPI Suite 4.1. Agilent Chemstation E.02.02.1431 was used for area integration of GC data for purity calculations.

\section{Preparation of stock and test solutions ${ }^{50}$}

Phosphate buffer solution (PBS) at $0.12 \mathrm{~mol} \mathrm{~L}^{-1}$, $\mathrm{pH} 7.60 \pm 0.10$, was prepared with $16.46 \mathrm{~g}$ of $\mathrm{Na}_{2} \mathrm{HPO}_{4} \cdot 2 \mathrm{H}_{2} \mathrm{O}$ and $3.71 \mathrm{~g}$ of $\mathrm{NaH}_{2} \mathrm{PO}_{4} \cdot \mathrm{H}_{2} \mathrm{O}$ in $1 \mathrm{~L}$ of purified water. $\mathrm{pH}$ adjustment was done with aqueous $\mathrm{HCl}$ or $\mathrm{NaOH}$ at $1 \mathrm{~mol} \mathrm{~L}^{-1}$. DTNB was diluted at $0.4 \mathrm{mg} \mathrm{mL}^{-1}$ in PBS and acetylthiocholine iodide, at $1 \mathrm{mmol} \mathrm{L}^{-1}$ in PBS. Stock solutions 
of standard antidotes 2-PAM (13), OBD (14) and TMB (15) were prepared in DMSO at $10 \mathrm{mmol} \mathrm{L}^{-1}$ and diluted in PBS to achieve $900 \mu \mathrm{mol} \mathrm{L} \mathrm{L}^{-1}$ prior to use $\left(100 \mu \mathrm{mol} \mathrm{\textrm {L } ^ { - 1 }}\right.$ in wells after all dilutions) to avoid precipitation and vortexed before use. NEMP test solution was freshly prepared in absolute ethanol at $20 \mu \mathrm{mol} \mathrm{L}^{-1}\left(1 \mu \mathrm{mol} \mathrm{L} \mathrm{L}^{-1}\right.$ in wells after all dilutions). $E e \mathrm{AChE}$ stock solution was prepared at $125 \mathrm{U} \mathrm{mL}^{-1}$ in PBS ( $0.75 \mathrm{U} \mathrm{mL}^{-1}$ in each well after all dilutions) and stabilized with $1 \%$ bovine serum albumin (BSA). All solutions were stored at $0{ }^{\circ} \mathrm{C}$ prior to use, except for the enzyme solution, which was stored at $-20^{\circ} \mathrm{C}$. This stabilized stored solution can be used, at least, for six months.

\section{Data analysis}

Data are expressed as mean \pm standard deviation (SD) from three different measurements obtained from three different assays. Microsoft Excel ${ }^{\circledR} 2007$ was used for all calculations.

\section{One-pot synthesis of NEMP}

In a round-bottomed reaction flask (dried in oven at $120{ }^{\circ} \mathrm{C}$ for $20 \mathrm{~min}$ and cooled down under $\mathrm{N}_{2}$ flow) equipped with $\mathrm{N}_{2}$ flow (balloon), 1.0 equiv. of diethyl methylphosphonate $(100 \mathrm{mg})$ and five drops of DMF were added. This mixture was cooled at $10^{\circ} \mathrm{C}$ and oxalyl chloride ( $84.6 \mu \mathrm{L}, 1.5$ equiv.) was added slowly, with the temperature kept under $40{ }^{\circ} \mathrm{C}$. Then, the solventless reaction mixture was heated at $50{ }^{\circ} \mathrm{C}$ for $2.5 \mathrm{~h}$ and, then, was cooled down to room temperature. The reaction was followed up by GC-MS (artifacts as pyrophosphates may be seen) or ${ }^{31} \mathrm{P}$ NMR (best option). After consumption of the phosphonate, excess of oxalyl chloride was carefully evaporated and a solution of dry triethylamine ( $183 \mu \mathrm{L}, 2.0$ equiv.) in toluene $(2 \mathrm{~mL})$ and a solution of 4-nitrophenol (183 mg, 2.0 equiv.) in toluene $(5 \mathrm{~mL})$ were sequentially added. This mixture was stirred at room temperature for $2 \mathrm{~h}$ and, then, diluted with $20 \mathrm{~mL}$ of ethyl acetate and carefully washed with $20 \mathrm{~mL}$ of $2 \%$ aqueous sodium bicarbonate. The organic layer was separated, dried over anhydrous sodium sulfate and filtered under mild vacuum (washing with $20 \mathrm{~mL}$ of ethyl acetate). Finally, careful evaporation yields crude NEMP as a yellow oil. As it is a potential AChE inhibitor, it must be manipulated with precaution. Therefore, it was not purified to avoid increasing toxicity risks. ${ }^{37}$

\section{Ellman's test procedures ${ }^{50}$}

Ellman's test procedure for inhibition of EeAChE by NEMP

The instrument temperature was set and the absorbance of empty microplate determined. In a clean, $10 \mathrm{~mL}$ glass vial, EeAChE $\left(120 \mu \mathrm{L}, 125 \mathrm{U} \mathrm{mL}^{-1}\right)$ was dissolved in $6880 \mu \mathrm{L}$ PBS (enough for 96 wells). Then, the enzyme solution $\left(70 \mu \mathrm{L}, 2.14 \mathrm{U} \mathrm{mL}^{-1}\right)$, DTNB $\left(80 \mu \mathrm{L}, 0.4 \mathrm{mg} \mathrm{mL}^{-1}\right)$, NEMP solution $\left(1 \mu \mathrm{mol} \mathrm{L} \mathrm{L}^{-1}, 10 \mu \mathrm{L}\right.$, for positive control, $\mathrm{L}_{\mathrm{i}}$ (absorbance with inhibitor)) or solvent $(10 \mu \mathrm{L}$, employed in the inhibitor solution, for negative control, $\mathrm{L}_{0}$ (absorbance without inhibitor)) and PBS $(20 \mu \mathrm{L})$ were pipetted to each well. After $10 \mathrm{~min}$ of incubation, the acetylthiocholine iodide solution $(20 \mu \mathrm{L})$ was added and the absorbance at $412 \mathrm{~nm}$ was read at 10,20 and $30 \mathrm{~min}$ to calculate enzyme inhibition.

\section{Ellman's test procedure for reactivation of EeAChE inhibited} by NEMP50

Under the same experimental conditions, to each well, the enzyme solution ( $70 \mu \mathrm{L}, 2.14 \mathrm{U} \mathrm{mL}^{-1}$ ), DTNB ( $\left.80 \mu \mathrm{L}, 0.4 \mathrm{mg} \mathrm{mL}^{-1}\right)$, NEMP solution $(10 \mu \mathrm{L}$, for positive control, absorbance $\mathrm{L}_{\mathrm{i}}$ ) or inhibitor solvent (10 $\mu \mathrm{L}$, for negative control, absorbance $\mathrm{L}_{0}$ ) were pipetted, followed by incubation for $10 \mathrm{~min}$. Then, the antidote standard solution (2-PAM (9) or OBD (10) or TMB (11), $20 \mu \mathrm{L}$ ) was added, followed by incubation for $10 \mathrm{~min}$. At last, the acetylthiocholine iodide solution $(20 \mu \mathrm{L})$ was added and the absorbance at $412 \mathrm{~nm}$ was read after $10 \mathrm{~min}$ to determine the enzyme reactivation.

\section{Results and Discussion}

\section{One-pot synthesis of NEMP}

The synthetic procedure for NEMP is depicted in Scheme 4. In contrast to the literature procedure, ${ }^{37}$ we employed $O, O$-diethyl methylphosphonate (22) as a starting material to yield $O$-ethylmethylphosphonochloridate (23, Scheme 4), which is less reactive than methylphosphonyl dichloride, the precursor previously used in the literature. As we also employed oxalyl chloride, a mild chlorinating agent, a cleaner reaction and a product of higher purity resulted. Besides, no solvent was used in the chlorination step. This methodology, starting from $O, O$-dialkyl alkylphosphonates, may also be applicable to the synthesis of other surrogates.

Monochlorination of $O, O$-diethyl methylphosphonate (22) with oxalyl chloride and DMF (nucleophilic catalyst), in a solventless medium, under mild conditions, afforded $O$-ethyl methylphosphonochloridate (23, not isolated). After removal of excess of the chlorinating agent by careful evaporation, this intermediate reacted with 4-nitrophenol and triethylamine in toluene, a less toxic solvent, instead of benzene, employed in previous reports. ${ }^{37}$ The produced crude NEMP displayed a higher purity compared to the 


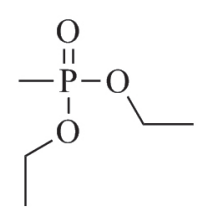

22

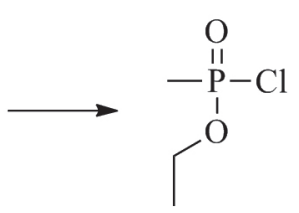

23

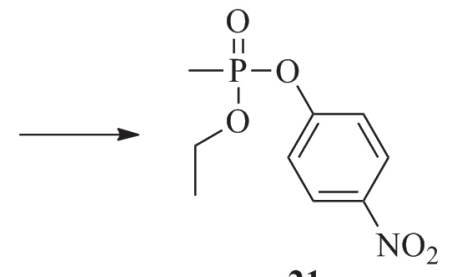

21

Scheme 4. One-pot synthesis of NEMP via methylphosphonochloridate (23): (i) oxalyl chloride (1.5 equiv.), DMF (catalytic), $50^{\circ} \mathrm{C}, 2.5$ h; (ii) 4 -nitrophenol (2 equiv.), triethylamine ( 2 equiv.), toluene, $2 \mathrm{~h}$, rt.

previously described procedure, being the major impurity 4-nitrophenol (by GC-MS and ${ }^{1} \mathrm{H}$ NMR analyses), similarly to the literature method ${ }^{37}$ Nevertheless, we reckon that the use of a less reactive starting material, mild chlorinating agent and less toxic solvent makes this procedure more appealing. Recently, we had achieved the synthesis of NEMP from diethyl methylphosphonate obtained via Michaelis-Arbuzov reaction with triethyl phosphite in a pressure tube (vide supra), ${ }^{38}$ which we have explored for syntheses of other surrogates.

NEMP was obtained as a yellow oil in higher yield. In its ${ }^{1} \mathrm{H}$ NMR spectrum a doublet can be seen at $1.74 \mathrm{ppm}\left(\mathrm{CH}_{3} \mathrm{P}\right.$, ${ }^{2} J_{\mathrm{HP}} 17.74 \mathrm{~Hz}$ ). At $4.23 \mathrm{ppm}$, a complex pattern related to the methylene moiety from $O$-ethyl group is observed. This is due to the diastereotopic nature of methylene protons at the ethyl group, as the phosphorus atom is chiral. Additionally, two aromatic doublets at $7.38 \mathrm{ppm}\left(2 \mathrm{H},{ }^{3} J_{\mathrm{HH}} 9.14 \mathrm{~Hz}\right)$ and $8.25 \mathrm{ppm}\left(2 \mathrm{H},{ }^{3} J_{\mathrm{HH}} 9.15 \mathrm{~Hz}\right)$, related to the 4-nitrophenyl group, are present. ${ }^{31} \mathrm{P}$ NMR of this compound shows an intense signal at $30.35 \mathrm{ppm}$. Finally, the mass spectrum displayed the $m / z, 245$, molecular ion peak at $t_{R}$ (retention time) $17.526 \mathrm{~min}$. The major impurity was identified as 4-nitrophenol, by both GC-MS $\left(\mathrm{t}_{\mathrm{R}}=14.993 \mathrm{~min}, \mathrm{~m} / \mathrm{z}\right.$ 139) and ${ }^{1} \mathrm{H}$ NMR (aromatic protons at 6.90 and $8.10 \mathrm{ppm}$ ). Purity was accessed either by GC or ${ }^{1} \mathrm{H}$ NMR. By Agilent Chemstation GC MS algorithm, we achieved $84 \%$ of purity, while ${ }^{1} \mathrm{H}$ NMR analysis retrieved $80 \%$. Again, comparison with the purity achieved by the literature methods $(69 \%)^{37-39}$ clearly shows improvement.

Similarly to the literature procedure, ${ }^{37-39}$ we decided to use crude NEMP, without further purification. Given its predictable toxic properties, as a pentavalent organophosphorus compound, we tried to avoid manipulation risks. Our aim was to obtain a compound that yields the same VX-adduct with AChE, but employing a non-Schedule I CWC chemical, for a more realistic evaluation of our antidote candidates.

\section{Inhibition of EeAChE with NEMP}

We tested this crude synthetic sample as AChE inhibitor, measuring the enzyme activity using Ellman's test. As AChE is conserved across species, we decided to use commercially available $E e A C h E$. After a 10 min-incubation of EeAChE with $1 \mu \mathrm{mol} \mathrm{L} \mathrm{L}^{-1}$ of NEMP, up to $95 \%$ of enzyme inhibition was attained, confirming the synthesized NEMP as a potent inhibitor. The inhibition level (\%I) was calculated by equation 1 , wherein $\mathrm{L}_{0}$ stands for the absorbance without inhibitor and $\mathrm{L}_{\mathrm{i}}$, for the absorbance with inhibitor. Results for $E e \mathrm{AChE}$ inhibition in different times are shown in Table 1. Concentration was chosen in accordance to literature, ${ }^{28,29,31,32}$ which ranges from $10^{-5}$ to $10^{-9} \mathrm{~mol} \mathrm{~L}^{-1}$. It is noteworthy that the enzyme is not to be fully inhibited, so as to prevent misinterpretation of reactivation data.

$\% \mathrm{I}=\left(\left[\frac{\mathrm{L}_{0}-\mathrm{L}_{\mathrm{i}}}{\mathrm{L}_{0}}\right]\right) \times 100$

Table 1. Enzyme inhibition results ${ }^{\mathrm{a}}$ (mean \pm standard deviation, SD)

\begin{tabular}{lccc}
\hline \multirow{2}{*}{ NEMP } & \multicolumn{3}{c}{ Reading time / min } \\
\cline { 2 - 4 } & 10 & 20 & 30 \\
\hline $\begin{array}{l}\text { Enzyme inhibition } \\
(\% \mathrm{I} \pm \text { SD }) / \%\end{array}$ & $95 \pm 2$ & $95 \pm 2$ & $94 \pm 2$ \\
\hline
\end{tabular}

a Condition: 10 min-incubation with $1 \mu \mathrm{mol} \mathrm{L} \mathrm{L}^{-1}$ of $\operatorname{NEMP}(O$-(4-nitrophenyl) $O$-ethyl methylphosphonate).

We chose an enzyme source (commercial EeAChE) different from literature ones, extracted from tissues or direct analysis in vivo. ${ }^{37}$ Therefore, it exhibited different activity. Nevertheless, based on results described in Table 1, we can state that the crude NEMP by our route was able to similarly inhibit the enzyme in high level in comparison with published data. ${ }^{37}$ This proves its usefulness as a tool for toxicological and biochemical studies.

Reactivation of NEMP-inhibition EeAChE with standard antidotes

EeAChE reactivation (\%R) was calculated by using the equation 2, wherein $\mathrm{L}_{\mathrm{r}}$ stands for the absorbance after addition of reactivator. The results for enzyme reactivation 
Table 2. Enzyme reactivation (mean \pm standard deviation, SD)

\begin{tabular}{lccccc}
\hline Antidote & $\mathrm{rAChE}(\% \mathrm{R} \pm \mathrm{SD})^{\mathrm{a}} / \%$ & $\mathrm{p} K_{\mathrm{a}}$ & $\log \mathrm{P}$ & $\mathrm{K}_{\text {Ow }}$ & Water solubility $\left(25^{\circ} \mathrm{C}\right) /\left(\mathrm{mg} \mathrm{L}^{-1}\right)$ \\
\hline 2-PAM & $21 \pm 1$ & 7.63 & -3.26 & 1.22 & 83941 \\
OBD & $46 \pm 1$ & $7.51,8.11$ & -6.93 & 2.60 & 77.105 \\
TMB & $39 \pm 1$ & $8.63,9.24$ & -7.04 & 1.95 & 5031.3 \\
\hline
\end{tabular}

${ }^{a}$ All oximes were tested at $100 \mu \mathrm{mol} \mathrm{L}{ }^{-1}$. EeAChE was previously inhibited over 10 min by NEMP (O-(4-nitrophenyl) $O$-ethyl methylphosphonate) at $1 \mu \mathrm{mol} \mathrm{L}{ }^{-1}$. $\mathrm{rAChE}$ : AChE reactivation (in percentage); $\mathrm{K}_{\mathrm{Ow}}$ : octanol/water partition coefficient; 2-PAM: pralidoxime iodide; OBD: obidoxime dichloride; TMB: trimedoxime dibromide.

using standard antidotes 2-PAM (13), OBD (14) and TMB (15) at $100 \mu \mathrm{mol} \mathrm{L}{ }^{-1}$, the highest attainable concentration in vivo, ${ }^{51,52}$ following inhibition by $\operatorname{NEMP}\left(1 \mu \mathrm{mol} \mathrm{L}{ }^{-1}\right)$ over $10 \mathrm{~min}$, are shown in Table 2.

$\% \mathrm{R}=\left(1-\left[\frac{\mathrm{L}_{0}-\mathrm{L}_{\mathrm{r}}}{\mathrm{L}_{0}-\mathrm{L}_{\mathrm{i}}}\right]\right) \times 100$

The data in Table 2 further confirm the formation of the VX-adduct via our synthesized NEMP. The observed reactivation levels, with OBD and TMB surpassing 2-PAM, are consistent with the published data. ${ }^{37}$ The lower OBD $\mathrm{p} K_{\mathrm{a}}$, combined with additional interactions by the second cationic moiety, possibly justifies its higher activity. The other physicochemical data $\left(\log \mathrm{P}, \mathrm{K}_{\mathrm{OW}}\right.$ and water solubility) relate to the ease of hematoencephalic barrier crossing, a relevant issue in the pharmacokinetics of these drugs.

\section{Conclusions}

We herein report a straightforward, one-pot synthesis of NEMP, $O$-(4-nitrophenyl) $O$-ethyl methylphosphonate, VX surrogate. The obtained crude material was shown to successfully inhibit EeAChE. Assays of reactivation of NEMP-inhibited $E e A C h E$ by three known antidotes were undertaken. For such experiments, we followed a set of guidelines which we had previously disclosed for the involved Ellman's tests, which enables a safer first approach to the technique. We hope, by presenting these methodologies, to encourage other groups to perform research on novel reactivators for AChE using diverse surrogates, non-prohibited, less-toxic compounds, whose use abides to CWC and do not require expensive laboratory's preparedness.

\section{Supplementary Information}

Supplementary information $\left({ }^{1} \mathrm{H},{ }^{13} \mathrm{C}\right.$ and ${ }^{31} \mathrm{P}$ NMR, total/ extracted ion chromatograms and mass spectra of NEMP total/extracted ion chromatograms and mass spectrum for major impurity detected, 4-nitrophenol) is available free of charge at http://jbcs.sbq.org.br as PDF file.

\section{Acknowledgments}

Authors would like to thank Dr M. Pohanka and Dr K. Kuča for providing relevant literature and advice; Central Analítica (IPPN/UFRJ) and Núcleo de Competência para o Desenvolvimento de Tecnologias de Carbono (NCDTC) for NMR spectra. S. F. A. C. gratefully acknowledges to Organisation for the Prohibition of Chemical Weapons (OPCW) for research grant (L/ICA/ICB/201062/15) and Brazilian Army for providing infrastructure.

\section{References}

1. https://www.opcw.org/about-us/history, accessed in December 2018.

2. http://www.sciencediplomacy.org/perspective/2015/ intersection-science-and-chemical-disarmament, accessed in April 2018.

3. Delfino, R. T.; Ribeiro, T. S.; Figueroa-Villar, J. D.; J. Braz. Chem. Soc. 2009, 20, 407.

4. https://www.opcw.org/chemical-weapons-convention, accessed in December 2018.

5. https://www.opcw.org/fileadmin/OPCW/S_series/2018/en/s1621-2018_e_.pdf, accessed in August 2018.

6. https://www.opcw.org/news/article/statement-from-opcwspokesperson-in-response-to-media-queries-regarding-allegeduse-of-nerve-agent-vx-in-malaysia/, accessed in February 2018.

7. https://sputniknews.com/asia/201703031051219306-opcwkim-jong-nam-probe/, accessed in February 2018.

8. http://www.channelnewsasia.com/news/asiapacific/malaysiato-fully-cooperate-with-opcw-on-vx-probe-ministry/3564532. html, accessed in February 2018.

9. http://yle.fi/uutiset/3-9503798, accessed in February 2018.

10. http://www.bbc.com/news/world-europe-43835774, accessed in April 2018.

11. Quinn, D. M.; Chem. Rev. 1998, 87, 955.

12. Taylor, P.; J. Biol. Chem. 1991, 266, 425.

13. Kumar, A.; Singh, A.; Ekavali; Pharmacol. Rep. 2015, 67, 195. 
14. Gorecki, L.; Korabecny, J.; Musilek, K.; Malinak, D.; Nepovimova, E.; Dolezal, R.; Jun, D.; Soukup, O.; Kuča, K.; Arch. Toxicol. 2016, 90, 2831.

15. Taylor, P.; Radić, Z.; Annu. Rev. Pharmacol. Toxicol. 1994, 34, 281.

16. Soreq, H.; Seidman, S.; Nat. Rev. Neurosci. 2001, 2, 294.

17. Silman, I.; Sussman, S. L.; Curr. Opin. Pharmacol. 2005, 5 , 293.

18. Hörnberg, A.; Tunemalm, A. K.; Ekström, F.; Biochemistry 2007, 46, 4815.

19. Bartling, A.; Worek, F.; Szinicz, L.; Thiermann, H.; Toxicology 2007, 233, 166.

20. Nicolet, Y.; Lockridge, O.; Masson, P.; Fontecilla-Camps, J. C.; Nachon, F.; J. Biol. Chem. 2003, 278, 41141.

21. Bencsura, A.; Enyedy, I. Y.; Kovach, I. M.; J. Am. Chem. Soc. 1996, 118, 8531 .

22. Lushington, G. H.; Guo, J. X.; Hurley, M. M.; Curr. Top. Med. Chem. 2006, 6, 57.

23. Sussman, J. L.; Harel, M.; Silman, I.; Chem.-Biol. Interact. 1993, 87, 187.

24. Tougu, V.; Curr. Med. Chem. 2001, 1, 155.

25. Pohanka, M.; Biomed. Pap. Med. Fac. Palacky Univ. Olomouc 2011, 155, 219.

26. Silman, I.; Sussman, J. L.; Chem.-Biol. Interact. 2008, 175, 3.

27. Millard, C. B.; Kryger, G.; Ordentlich, A.; Greenblatt, H. M.; Harel, M.; Raves, M. L.; Segall, Y.; Barak, D.; Shafferman, A.; Silman, I.; Sussman, J. L.; Biochemistry 1999, 38, 7032.

28. Milatovic, D.; Jokanovic, M. In Elsevier Handbook of Toxicology of Chemical Warfare Agents; Gupta, R. C., ed.; Elsevier: New York, USA, 2009, ch. 65, p. 965.

29. Kuča, K.; Mušilek, K.; Jun, D.; Bajgar, J.; Kassa, J. In Elsevier Handbook of Toxicology of Chemical Warfare Agents; Gupta, R. C., ed.; Elsevier: New York, USA, 2009, ch. 66, p. 997.

30. Worek, F.; Wille, T.; Koller, M.; Thiermann, H.; Chem.-Biol. Interact. 2013, 203, 125.

31. Hobbiger, F.; Pitman, M.; Sadler, P. W.; Biochem. J. 1960, 75, 363.

32. Hagedorn, I.; Stark, I.; Lorenz. H. P.; Angew. Chem., Int. Ed. Engl. 1972, 11, 307.

33. Cannard, K.; J. Neurol. Sci. 2006, 249, 86.

34. Kuča, K.; Jun, D.; Mušilek, K.; Mini-Rev. Med. Chem. 2006, $6,269$.
35. Eddleston, M.; Buckley, N. A.; Eyer, P.; Dawson, A. H.; Lancet 2008, 371, 597.

36. Mercey, G.; Verdelet, T.; Renou, J.; Kliachyna, M.; Baati, R.; Nachon, F.; Jean, L.; Renard, P. Y.; Acc. Chem. Res. 2012, 45, 756.

37. Meek, E. C.; Chambers, H. W.; Coban, A.; Funck, K. E.; Pringle, R. B.; Ross, M. K.; Chambers, J. E.; Toxicol. Sci. 2012, 126, 525.

38. Cavalcante, S. F. A.; de Paula, R. L.; Kitagawa, D. A. S.; Barcellos, M. C.; Simas, A. B. C.; Granjeiro, J. M.; J. Phys.: Conf. Ser. 2018, 975, 012020.

39. Ellman, G. L.; Arch. Biochem. Biophys. 1959, 82, 70.

40. Ellman, G. L.; Courtney, K. D.; Andres Jr., V.; Featherstone, R. M.; Biochem. Pharmacol. 1961, 7, 88.

41. Worek, F.; Eyer, P.; Thiermann, H.; Drug Test. Anal. 2012, 4, 282.

42. Pohanka, M.; Jun, D.; Kuča, K.; Talanta 2008, 77, 451.

43. Pohanka, M.; Drtinova, L.; Talanta 2013, 106, 281.

44. Jarvinen, P. P.; Fallarero, A.; Gupta, S.; Mohan, G. C.; Hatakka, A. I.; Vuorela, P. M.; Comb. Chem. High Throughput Screening 2010, 13, 278.

45. Pohanka, M.; Hrabinova, M.; Kuča, K.; Simonato, J. P.; Int. J. Mol. Sci. 2011, 12, 2631.

46. Pohanka, M.; Jun, D.; Kuča, K.; J. Enzyme Inhib. Med. Chem. 2008, 23, 781.

47. Järvinen, P. P.; Vuorela, P.; Hatakka, A.; Fallarero, A.; Anal. Biochem. 2011, 408, 166.

48. Kuča, K.; Cabal, J.; Patocka, J.; Kassa, J.; Lett. Org. Chem. 2004, 1, 84.

49. Musílek, K.; Lipka, L.; Račáková, V.; Kuča, K.; Jun, D.; Dohnal, V.; Doležal, M.; Chem. Pap. 2006, 60, 48.

50. Cavalcante, S. F. A.; Kitagawa, D. A. S.; Rodrigues, R. B.; Cardozo, M.; de Paula, R. L.; Correa, A. B. A.; Simas, A. B. C.; Quim. Nova 2018, 41, 1192.

51. Tattersall, J. E. H.; Br. J. Pharmacol. 1993, 108, 1006.

52. Kuča, K.; Kassa, J.; J. Enzyme Inhib. Med. Chem. 2003, 18, 529.

Submitted: June 1, 2018

Published online: December 14, 2018 